\title{
Üniversite Öğrencilerinde Psikolojik Kırılganlıkla Öznel Zindelik Arasındaki İlişkide Genel Psikolojik Sağlı̆̆ın Aracı Rolü
}

\section{The Mediating Role of General Psychological Health in Relation between Psychological Vulnerability and Subjective Vitality on University Students}

\author{
Halil Ekşi, ${ }^{a}$ Deniz Erök Özkapu, ${ }^{\mathrm{b}}$ Durmuş Ümmet ${ }^{\text {c* }}$ \\ aProf. Dr., Marmara Üniversitesi, Eğitim Fakültesi, Eğitim Bilimleri Bölümü, İstanbul/Türkiye. \\ ORCID: https://orcid.org/ 0000-0001-7520-4559
}

'Psk. Danışman., Marmara Üniversitesi, Eğitim Fakültesi, Eğitim Bilimleri Bölümü, İstanbul/Türkiye. ORCID: https://orcid.org/ 0000-0002-6257-5788

'Doç. Dr.., Marmara Üniversitesi, Eğitim Fakültesi, Eğitim Bilimleri Bölümü, İstanbul/Türkiye. ORCID: https://orcid.org/0000-0002-8318-9026

\section{MAKALE BILGİSI}

\section{Makale Geçmişi:}

Başvuru tarihi: 12 Şubat 2019

Düzeltme tarihi: 23 Mart 2019

Kabul tarihi: 01 Nisan 2019

\section{Anahtar Kelimeler:}

Psikolojik kırılganlık

Öznel zindelik

Genel psikolojik sağlık

Aracılık rolü

Üniversite öğrencileri

\section{ARTICLE INFO}

\section{Article history:}

Received 12 February 2019

Received in revised form 23 March 2019

Accepted 01 April 2019

\section{Keywords:}

Psychological vulnerability,

Subjective vitality,

General psychological health,

Mediating role,

University students.
ÖZ

$\mathrm{Bu}$ araştırmanın amacı üniversite öğrencilerinde psikolojik kırılganlık ile öznel zindelik arasındaki iliş̧ide genel psikolojik sağlığın aracı rolünü incelemektedir. Bu amaç çerçevesinde araştırmada ilişkisel tarama yöntemi kullanılmıştır. Araştırmanın örneklemini 280'i kadın 73'ü erkek olmak üzere toplam 353 üniversite öğrencisi oluşturmaktadır. Öğrencilerin yaş ortalamaları 21.57'dir. Araştırmanın verilerini toplamak amacıyla Kişisel Bilgi Formu, Psikolojik Kırılganlık Ölçeği, Öznel Zindelik Ölçeği ve Genel Sağlık Ölçeği kullanılmıştır. İstatiksel yöntem olarak değişkenler arası ilişkileri belirlemek için Pearson Korelasyonu hesaplanmıştır. Aracılık rolünü belirlemek için Hiyerarşik Regresyon Analizi ve Sobel Testi'den yararlanılmıştır. Elde edilen bulgulara bakıldığında; üniversite öğrencilerinin öznel zindelikleri ile hem psikolojik kırılganlıkları hem de genel sağlıkları arasında negatif ilişkiler olduğu görülmüştür. Ayrıca kurulan modelde, genel psikolojik sağlığın psikolojik kırılganlıkla öznel zindelik arasında tam aracı rolü olduğu belirlenmiștir.

\section{A B S T R A C T}

The aim of the study is to carry out the mediating role of general psychological health in relation between psychological vulnerability and subjective vitality on university students. For this, relational screening method was used. The sample of the study consisted of 353 university students (280 female, 73 male; age mean: 21,57). Personal Information Form, Psychological vulnerability scale, subjective vitality scale and general health scale were applied to gather the data. Pearson correlation method was used as statistical method to identify the relation between variables. And to carry out the mediation role, Hierarchical Regression Analysis and Sobel Test were used. In the light of findings, it was seen that there was negative correlation between psychological vulnerability, subjective vitality and negative general health condition of university students. In addition to the model created, it was found that psychological health had the role of mediator between psychological vulnerability and subjective vitality. Various solutions were put forward by considering the findings.

\section{Giriş}

Günümüzde bireyin olumlu özelliklerini, güçlü yanlarını temel alan pozitif psikoloji; kişinin kuvvetli taraflarını göz ardı eden ve psikopatoloji temeline dayanan geleneksel psikolojinin bakış açısına karşı çıkarak psikoloji ve psikolojik danışma alanında ön plana çıkmıştır İkinci Dünya Savaşı sonrasındaki dönemde psikoloji, patolojiyi ve dolayısıyla da medikali odağına almış ve insanlara bu açıdan yaklaşmıştır. Toplumun savaştan çıkması, birçok

* Sorumlu yazar/Corresponding author

e-posta: dummet@marmara.edu.tr 
kişinin travmatik olaylara maruz kalması, acil müdahaleye gerek duyulması klinik müdahalelerin öncelik kazanmasına neden olmuştur (Keyes ve Lopez, 2002). Bu dönemlerde bireylerin sorun yaratan, zarar görmüss olan noktalarına odaklanılmıștır. Zor ve kötü durumda olan bireylere yardım etmek, iyi durumda olan bireylere yardım etmeye tercih edilmiş ve bireylerin olumlu yönleri üzerinde araştırma yapmanın işe yaramayacağı düşünülerek yalnızca hastalıklar üzerinde çalışılmıştır. Geleneksel psikoloji bireyin potansiyelini takdir etmekten uzaklaşarak, hasarlı davranışlara; olumsuz kavram ve duygulara yönelmiştir. Pozitif psikolojinin henüz öne çıkmadığı dönemlerde, psikoloji bilimi bireydeki olumsuzluklara çok fazla zaman ayırmıştır ve bireyin iyilik haliyle ilgili hiçbir olgu ya da durumla ilgilenmeye vakit kalmamıştır (Pawelski, 2003; Seligman, 2002).

Pozitif psikoloji ise, geleneksel psikolojinin tersine; iyi ve olumlu özelliklere odaklanma yolunda giderek bireylerin, toplumların işlevlerini sürdürebilmelerine ve iyilik hali içinde olmalarına katkı sağlayacak çalışma ve araştırmalara yoğunlaşmıştır (Gable ve Haith, 2005). Pozitif psikoloji sıklıkla pozitif düşünme, hiçbir şeyi dert etmeme üzerine temellendirilmiş bir düşünce biçimi olarak algılanabilmektedir. Tüm bu düşünülenlerin aksine pozitif psikoloji, tamamen bilimsel olarak yapılanmıştır. Pozitif psikoloji hayatın üstesinden nasıl daha iyi gelinebileceğine odaklanır (Seligman, 2002). Pozitif psikolojide bireyin kendini mutlu ve iyi hissettiği duruma ulaşması sadece ruhsal durumuyla alakalı değildir. $\mathrm{Bu}$ bakış açısına göre mutluluk bireyin hayatını bir melodi gibi ahenk içerisinde devam ettirebilmesinde gizlidir. Bireyin potansiyelini, başarılı olduğu yönlerini, kişisel olarak güçlü olduğu taraflarını keşfetmesi ve bir bütün olarak kendini geliştirmesi, pozitif psikolojinin temel amaçlarındandır. Öznel zindelik kavramı da önemli bir pozitif psikoloji kavramidır. Bireyin kendini hem ruhsal hem de fiziksel olarak iyi durumda hissetmesi, enerjik olması ve kendi potansiyelini ortaya koyabilmesini ifade ederek pozitif psikolojinin en temel amaçlarına vurgu yapmaktadır (Brunstein ve Maier, 2002). Öznel zindelik kavramı, pozitif psikolojinin kavramlarından olan öznel mutluluk ve iyilik hali içinde olmanın yapı taşlarından biri olarak ele alınmakta ve bireyin hem fiziksel hem de ruhsal yönden dinç durumda olması olarak tanımlanmaktadır (Ryan ve Frederick, 1997). Öznel zindelik kavramını içinde barındıran öznel iyi oluş kavramı; hem bilişsel hem de duyuşsal ögeleri kapsamaktadır. Bilişsel olarak gerçekçiliği ve entellektüelizmi içerirken duygusal olarak heyecan, neşe, ilgi, güven, uyanıklık gibi olumlu ve öfke, üzüntü, suçluluk, nefret gibi olumsuz duyguları içerir (Diener, Suh, Lucas ve Shmith, 1999). Alan yazınında öznel zindeliğin kendini gerçekleştirme, olumlu duygulanım, benlik saygısı, dışa dönüklük, içsel motivasyon ve yaşam memnuniyeti değişkenleriyle de olumlu yönde bir ilişki içerisinde olduğu bildirilmektedir (Ryan ve Frederick, 1997).

Mevcut kuramlar ve konuyla ilgili araştırma ve uygulamalar, psikolojik sağlık ile öznel zindeliğin birbiriyle ilişkili iki kavram olduğunu ortaya koymaktadır. Frued'a göre, bireyin yaşam süreçlerini yürütebilmesi için enerjiye ihtiyacı vardır ve bu enerjinin adı ruhsal enerjidir. Ruhsal enerjinin kaynağı cinsellik ve saldırganlık içgüdüleridir. Ruhsal enerji gözle görülebilen ve elle tutulabilen somut bir şey değildir. Ancak nasıl ki tüm gün evi temizlediğimizde başka işlere harcayacak enerjimiz kalmıyorsa ruhsal olarak da belirli yerlere yönlendirilen enerji tükenmektedir (Cansever, 1976). Eğer birey ruhsal enerjisini patolojik durumlara ya da kişiliğinin yalnızca belirli birkaç boyutuna yönlendirirse bu durum tüm yaşamına olumsuz yönde etki edecektir. Sonuçta birey kendi potansiyelinin farkına varamayacak ve kişiliğinin diğer boyutlarının gelişmesine engel olacaktır (Ryan ve Frederick, 1997). Analitik psikoloji yaklaşımının ortaya attığı psikolojik olarak sağlıklı bir birey olmakla doğrudan ilişki olan kendini gerçekleştirme kavramına bakıldığında biyolojik ihtiyaçların giderilmesinin ardından gelen manevi ihtiyaçların bulunduğu görülür. Bireylerin psikolojik olarak tam bir iyilik halinde olmaları manevi olarak kendilerini iyi, canlı ve enerjik hissetmelerine yani öznel olarak zinde hissetmelerine bağlıdır. Rank'a göre ise bireyin özerkleşmesi için irade sahibi ve güçlüklerle baş edebilen bir birey olması gereklidir ve öznel olarak zindelik hali içinde olan birey canlı, girişken ve yaşam olaylarına karşı daha dayanıklıdır (Akt. Kuzgun, 1972). Glasser'e göre bireylerin davranışlarının birbirinden ayrılmayan dört farklı bileşeni bulunmaktadır. $\mathrm{Bu}$ bileşenler; hareket etme, düşünme, hissetme ve fizyolojiden oluşmaktadır. Bileşenlere bakıldığında hareket etme ve fizyoloji kavramları bireyin fiziksel boyutunu; düşünme ve hissetme ise ruhsal yönünü yansıtmaktadır. $\mathrm{Bu}$ perspektiften bakıldığında bireyin psikolojik sağlığının belirleyicilerinden olan bu dört bileşenin öznel zindelik ile ilişki olduğu görülmektedir (Akt. Corey, 2008).

Alanyazın incelendiğinde, öznel zindeliğin depresif belirtilerle, bağımlılıklarla ve fiziksel belirtilerle negatif; duygusal iyi olma, sosyal iyi olma ve psikolojik iyi olma ile pozitif bir ilişki içinde olduğu görülmektedir. Bu bulgulara bakıldığında bireyin fiziksel ve ruhsal olarak zinde olması, hem psikolojik olarak hem de fiziksel olarak iyi durumda olmasıyla ilişkidir (Akın ve Akın, 2015; Can, 2017; Salama-Younes, 2011). Öznel zindelik, duygusal coşku haline benzetilebilir ancak öznel zindelikte duygusal coşku durumunda bulunan zorlanma ve hirs yoktur ve bu yönüyle olumlu bir olgu olarak tanımlanmaktadır (Bostic, Rubio ve Hood, 2000). Konuyla ilgili alan yazın incelendiğinde; hem genel psikolojik sağlığın öznel zindeliği etkilediği hem de öznel zindeliğin genel psikolojik sağlığı etkilediği söylenebilir. Alan yazında öznel zindeliği etkilediği ifade edilen bir diğer kavram ise psikolojik kırılganlıktır.

Kırılganlık kavramı, bireyin psikolojik, sosyal ve fiziksel yönlerden incinebilir olması olarak tanımlanmaktadır (Scanlon ve Lee, 2007). Sosyal kirllganlık; bireyin kolay bir şekilde çevresindeki kişi ve durumlara inanabilmesi, kolayca kandırılabilmesi ve istismar edilebilmesiyle ilintili bir kavramdır. Birey saflık hali içerisindedir. Çevresindeki insanlar onu sömürülebilecek birisi olarak algılayabilir.

Bu bağlamda bakıldığında sosyal kırılganlığın iki önemli olgusu aldatılabilirlik ve kolay inanırlıktır (Sarıçam, Uysal, İlbay, Çardak ve Akın, 2012). Psikolojik kırılganlık ise, bireyin benlik değerine ilişkin dışsal onaya ya da başarı ve başarısızlık durumuna göre geliştirmiş olduğu bilişsel inançlarıdır. Bireyler çevrelerindeki insanların tepkilerinden beklentilerinden, davranışlarından yola çıkarak kendi bilişsel yapılarını oluşturur. 
Kırılgan insanlar diğer insanlara oranla daha fazla olumsuz duygu durumu içerisinde bulunur ve stresli yaşam olaylarıyla başa çıkmakta zorlanırlar (Sinclair ve Wallston, 1999).Kırılganlık hakkındaki tüm bu bilgilerin 1şığında olgu ele alındığında; fiziksel kırılganlığın bireyin bedensel iyilik hali ile ilintili olduğu söylenebilir. Sosyal kırılganlık ve psikolojik kırılganlık kavramlarının ise bireyin daha çok ruhsal süreçleriyle, kişilik özelikleriyle ve kendilerine dair algılarıyla ilgili olduğu düşünülebilir. Psikolojik kırılganlık olgusunda genellikle bireyin çevresindeki insanların takdirine verdiği değere vurgu yapılırken sosyal kırılganlık olgusunda ise daha çok bireyin saf olmasına, kolayca inanabilme ve çeşitli konularda sömürülmesine izin verecek kişilik özelliklerine sahip olmasına vurgu yapıldığ görülmektedir ki hem sosyal kırılganlığın hem fiziksel kırılganlığın psikolojik kırılganlığı etkileyeceği düşünülmektedir.

Psikolojik kırılganlık; mükemmeliyetçilik, takdir ihtiyacı ve bağımlılık kavramlarıyla da ilişkilidir. Birey, davranış ve düşüncelerinde çevresindeki insanların onayını almaya büyük bir ihtiyaç duyar ve bunun sonucunda bu insanlara karşı bir bağımlılık geliştirir. Aynı zamanda herkesin takdirini kazanma amacı içerisinde olduğu için mükemmel olana ulaşmaya çalışır. Başarı ve başarısızlık durumlarına göre kendine değer biçer ve başarısızlığa tahammülü yoktur. Bu bağlamda psikolojik kırılganlık olgusunda öne çıkan iki kavram sosyal onay ve başarıdır (Clark, Stump, Miller ve Long, 2007; Crocker ve Park, 2003; Sinclair ve Wallston, 1999). Psikolojik kırılganlığın diğer değişkenlerle ilişkisini inceleyen araştırmalara bakıldığında; psikolojik olarak kırılgan bireylerin kendilerini toplum içerisinde yetersiz olarak algıladıkları sonucuna ulaşıldığı görülmektedir (Ingram ve Price, 2010;Levine, 2004).

Psikolojik kırılganlık ve psikolojik sağlamlık kavramları pozitif psikolojinin iki önemli olgusudur. İki kavram birbirlerine yakın anlamlar içeriyor gibi gözükse de aralarında belirgin farklılıklar bulunmaktadır. Latincede'ki resiliens kavramından türemiş olan psikolojik sağlamlık kelime anlamı olarak esnemek, dönebilmek anlamına gelmektedir (Greene, 2002). Kelimenin bir psikoloji terimi olarak kullanılma amacına bakıldığında bu konuda pek çok tanımın bulunduğu görülmektedir. Psikolojik sağlamlık Murphy'e (1987) göre bireyin zor olaylarla karşılaştığında nasıl baş ettiğiyle ilgilidir ve duruma uyum sağlamayı da içerir. Fraser, Richman ve Galinsky'e (1999) göre psikolojik sağlamlık ekstrem şartlar altında bireyin başarılı olması demektir. $\mathrm{Bu}$ ve buna benzer tanımları içeren alanyazın incelendiğinde psikolojik sağlamlık; sağlıklı baş etme yöntemlerini içeren ve bireyin adaptasyon sürecine katkı sağlayan koruyucu etmenlerin risk etmenleriyle etkileşimi sonucunda ortaya çıkan bir olgudur (Windle, 1999).

Alanyazın çerçevesinde psikolojik kırılganlık ve psikolojik sağlamlık kavramları beraberce incelendiğinde, psikolojik kırılganlığın daha çok bireyin çevresindeki kişilerle ilişkileri ve onlardan aldığı tepkilere yüklediği anlam ve algıları sonucunda oluşan duygu, düşünce ve davranışlarına dair bir kavram olduğu; psikolojik sağlamlığın ise bireyin yaşam koşulları karşısında göstermiş olduğu uyumla ve baş etme yöntemleriyle ilişkili olduğu söylenebilir.
Bireyde oluşan olumsuz inançların başta depresyon olmak üzere pek çok psikolojik rahatsızlığı tetiklediği bilinmektedir (Mongrain ve Blackburn 2005). Bireyde olumlu duygular azaldığında kırılganlığın da ilişkili olarak artacağı ve oluşan kırılganlığın bireyin psikolojik rahatsızlıklar yaşamasına neden olacağı belirtilmektir (Crocker, 2002). Yapılan araştırmalar psikolojik kırılganlığın; depresyon, kendine yabancılaşma, yalnızlık, çaresizlik ve sağlıklı olmayan mekanizmalarla pozitif; yaşamdan zevk alma, yeni deneyimlere açık olma ile negatif bir ilişki içerisinde olduğunu göstermektedir (Akt.: Sinclair ve Wallston, 1999). Alanyazın incelendiğinde elde edilen bilgilerden yola çıkılarak psikolojik kırılganlığın öznel iyi oluşu yordayabileceği düşünülmektedir (Satıcı, 2016). Önceden de belirtildiği gibi öznel zindelik öznel iyi oluşun yap1 taşlarından biridir. Bu bağlamda psikolojik kırılganlık ile öznel zindelik arasındaki ilişkide genel psikolojik sağlık durumunun önemli bir rol oynayacağı düşünülmektedir. Öte yandan bireyin kendi görüş ve düşüncelerine daha fazla değer vermesi, koşulsuz ve şartsız olarak kendini önemsemesi psikolojik kırılganlığını azaltacaktır. Kırılganlığı azalan bireyin sosyal zorlanma düzeyi de azalacak ve yaşam olaylarıyla daha sağlıklı şekilde başa çıkarak, hayattan daha fazla zevk alarak yaşayacaktır (Ekşi, Bikeç ve Ümmet, 2017).Tüm bu bulgular beraberce değerlendirildiğinde; öznel zindelik kavramı fiziksel ve ruhsal olmak üzere iki boyutu barındırmaktadır. Alan yazınında var olan kuramlar, bireyin psikolojik olarak sağlıklı olmasının fiziksel ve ruhsal olarak sağlıklı olması ile ve yaşamdan doyum sağlamasıyla mümkün olduğunu ifade etmektedir. Psikolojik kırılganlık kavramının ise bireyin yaşam olaylarıyla başa çıkma, yeni deneyimlere açık olma, sağlıklı baş etme yöntemlerine sahip olma gibi olguları negatif yönde etkileyebileceği görülmektedir.

$\mathrm{Bu}$ çerçevede, araştırmada üniversite öğrencilerinin psikolojik kırılganlıkları ile öznel zindelikleri arasında genel psikolojik sağlığın aracı rolü olup olmadığı incelenmiştir. $\mathrm{Bu}$ amaç çerçevesinde aşağıdaki araştırma sorularına yanıt aranmıştır.

(i) Psikolojik kırılganlık ile öznel zindelik puanları arasında anlamlı bir ilişki var mıdır?

(ii) Genel psikolojik sağlık ile öznel zindelik puanları arasında anlamlı bir ilişki var mıdır?

(iii) Psikolojik kırılganlık ile genel psikolojik sağlık puanları arasında anlamlı bir ilişki var mıdır?

(iv) Psikolojik kırılganlık ile öznel zindelik puanları arasındaki ilişkide genel psikolojik sağlığın aracı rolü var midir?

\section{Yöntem}

Bu kısımda araştırmanın modeli, evren ve örneklemi, kullanılan veri toplama araçları, verilerin toplanması ve veri analizi süreci aktarılmıştır.

\subsection{Araştırma Modeli}

$\mathrm{Bu}$ araştırma, üniversite öğrencilerinin öznel zindeliklerinde genel psikolojik sağlıklarının ve psikolojik kırılganlıklarının rolünü incelemek üzere hazırlanan ilişkisel tarama modelinde bir çalışmadır. İlişkisel tarama modeli, iki ya da daha fazla değişken arasındaki birlikte 
değişimin varlığını ve/veya derecesini belirlemeyi amaçlayan araştırma modeli olarak tanımlanmaktadır (Karasar, 1999).

\subsection{Evren ve Örneklem}

Araştırmanın evreni 2017-2018 yılı bahar dönemi, Marmara Üniversitesi Atatürk Eğitim Fakültesi'nde eğitimine devam eden 3327 öğrenciden oluşmaktadır. Araştırmanın örneklemi ise evrenden tabakalı örnekleme yöntemi ile seçilen 280'ni kadın 73'ü erkek olmak üzere toplam 353 öğrenci oluşturmaktadır. Öğrencilerin yaşları ortalaması 21,57 olarak hesaplanmıştır. Tabakalı örnekleme, çerçevesi belirli olan bir evrende alt tabakalar veya alt birim gruplarının var olduğu durumlarda kullanılır (Özdamar, 2001). Tabakalı örnekleme yöntemiyle araştırmanın örneklemi belirlenirken üniversiteye yerleşmede etkili olan puan türüne göre 6 tabaka belirlenmiş ve bu tabakalardan (sayısal, sözel, eşit ağırlık, dil, özel yetenek, YGS puan türüyle öğrenci alan bölümler) tesadüfi küme örnekleme yöntemi ile katılımcılar seçilmiştir. Örneklemi oluşturan öğrenciler için tesadüfi küme örnekleme yapılırken araştırmaya dâhil olan programlar; İngilizce Öğretmenliği $(\mathrm{n}=80, \% 22,66)$, Türk Dili ve Edebiyatı Öğretmenliği $(n=42, \% 11,89)$, Beden Eğitimi Öğretmenliği $(n=45$, $\% 12,74)$, Resim Öğretmenliği ( $n=53, \% 15,01)$, Matematik Öğretmenliği (n=66, \%18,69), Fizik Öğretmenliğidir(n=67, $\% 18,98)$. Öğrencilerin 78'i, (\%22,09) 1. sinıfta, 72'si, $(\% 20,39)$ 2. sinifta, 96's1, $(\% 27,19)$ 3. sinifta ve 107'si, (\%30,31) 4. sınıfta öğrenim görmektedir.

\subsection{Veri Toplama Araçları}

Kişisel Bilgi Formu: Araştırmaya katılan kişilerin cinsiyet, yaş ve okudukları bölümleri belirlemek için araştırmalarca hazırlanan bir formdur.

Genel Sağlık Ölçeği: Genel Sağlık Ölçeği'nin orijinal formu Manchester Üniversitesi'nde David Goldberg (1972) tarafından geliştirilmiştir. İlk olarak Kılıç (1992) tarafından ölçek 34 madde olarak Türkçe'ye uyarlamıştır. Ölçek hem toplumda hem de psikiyatrinin haricindeki muayene ortamlarında ruhsal hastalıkların tespiti amacıyla oluşturulmuştur. Kılıç ve arkadaşları (1997) tarafından ölçeğin 12 maddelik kısa formu geliştirilmiştir. $\mathrm{Bu}$ araştırmada kullanılan ölçeğin kısa formudur. Geliştirilen bu formun iç tutarlılık katsayısı; .78, test- tekrar-test korelasyonu; $.84(\mathrm{p}<.001)$, iki yarım güvenilirliği;.81 bulunmuştur. Ölçeğin ölçüt geçerliğine orijinal formundan Türkçe'ye Öztürk ve arkadaşları (1974) tarafından uyarlanan "Şimdiki Durum Muayenesi" ile bakılmıştır. Ölçek 0 (hayır) ile 3 (çok sık) arasında puanlanmaktadır ve ölçekten alınabilecek puanlar 0 ile 36 puan aralığındadır. Örneğin,"Kendinizi mutsuz ve çökkün hissediyor musunuz?" sorusunda olduğu gibi olumsuz psikolojik sağlığı ölçen sorulardan oluşmaktadır. Yüksek puanlar olumsuz genel psikolojik sağlığa işaret etmektedir (Kılıç, 1996). $\mathrm{Bu}$ araştırma için ölçeğin güvenirlik katsayısı yeniden hesaplanmış ve Cronbach alfa değeri .822 olarak bulunmuştur.

Psikolojik Kırılganlık Ölçeği: Orijinal formunun Sinclair ve Wallston (1999) tarafından geliştirilen ölçeğin Türkçe'ye uyarlama geçerlik ve güvenirlik çalışmasını Akın ve Eker (2011) yapmıştır. Yetişkinlerin psikolojik kırılganlık düzeylerini belirlemeyi amaçlayan bu ölçek 6 maddeden oluşan 5'li likert tipi bir ölçektir. Ölçekten alınan yüksek puan yüksek psikolojik kırılganlığa işaret etmektedir. "Kendimi iyi hissetmek için diğerleri tarafindan onaylanmaya ihtiyaç duyarım" örnek maddesinde olduğu gibi psikolojik kırılganlığa işaret eden maddeler içermektedir. Tek boyutlu psikolojik kırılganlık modelinin doğrulanması amaciyla 371 üniversite öğrencisinden elde edilen verilere uygulanan doğrulayıcı faktör analizi sonucunda ölçeğin orijinal formda olduğu gibi tek boyutta iyi uyum verdiği bulunmuştur $\left(\chi^{2}=7.82, \quad \mathrm{sd}=9.00\right.$, $\mathrm{RMSEA}=.00, \mathrm{NFI}=.97, \mathrm{CFI}=1.00, \mathrm{GFI}=.99, \mathrm{AGFI}=.98$, $\mathrm{RFI}=.95, \mathrm{SRMR}=.02)$. Ölçeğin Cronbach alfa iç tutarlılık güvenirlik katsayısı .75 olup ölçeğin düzeltilmiş madde toplam korelasyon katsayılarının .26 ile .44 arasında değiştiği bulunmuştur.Bu araştırma için ölçeğin güvenirlik katsayısı yeniden hesaplanmış ve Cronbach alfa değeri .731 olarak bulunmuştur.

Öznel Zindelik Ölçeği: Öznel Zindelik Ölçeğinin orijinal formu 1997 yılında Ryan ve Frederick (1997) tarafindan geliştirilmiştir. Ölçeğin Türk kültürüne uyarlanması ve psikometrik özelliklerinin incelenmesi çalışmasını 2014 yılında Uysal, Sarıçam ve Akın yapmıştır. Ölçeğin ölçüt geçerliğine bakılmak amacıyla "Öznel Mutluluk Ölçeği" kullanılmıştır. Uysal, Sarıçam ve Akın ölçeğin Türkçe 'ye uyarlanması aşamasında yapı geçerliğinin sağlanması amacıyla açıklayıcı faktör analizi (AFA) ve doğrulayıcı faktör analizi (DFA) yapmıştır. Uygulanan AFA sonucunda toplam varyansın \%48.62'sini açıklayan, 7 maddeden oluşan ve öz değeri 1.00'in üzerinde olan tek faktörlü bir yap1 elde edilmiştir. Maddelerin faktör yükleri .30 ile .88 arasında sıralanmaktadır. Bu bulgulara göre ölçeğin madde faktör yapısının Türk kültürüne uygun olduğu fakat maddelerin doğrulanması gerektiği sonucuna ulaşılmıştır. Ölçekten alınan puan arttıkça öznel zindelik artmaktadır. "Kendimi enerji dolu hissederim" örnek maddesi gibi maddeler öznel zindeliğe işaret etmektedir. Uygulanan DFA sonucunda uyum indeksi değerleri: $\chi^{2}=12.17, \mathrm{sd}=7$, $\mathrm{p}=0.09517$ RMSEA $=.047$, AGFI=.96, GFI=.99, NFI=.99, $\mathrm{RFI}=.97$ ve $\mathrm{SRMR}=.023$ olarak bulunmuştur ve ölçeğin faktör yükleri .29 ile .86 arasında sıralanmaktadır. Bu araştırma için ölçeğin güvenirlik katsayısı yeniden hesaplanmış ve Cronbach alfa değeri .879 olarak bulunmuştur.

\subsection{Verilerin Toplanması ve Analizi}

Araştırmaya katılımda gönüllük esasına uyulmuş olup; araştırmanın amacı ve yöntemi açıklanarak, gizlilik ilkesine sayg1 gösterilerek yapılmıştır. Veriler araştırmacılar tarafından gerekli izinler alındıktan sonra yüz yüze gerçekleştirilmiştir. Uygulamalar ortalama 20 dakika sürmüştür. Araştırmada toplam 370 kişiye ulaşılmış ancak analize dahil edilmesinin sağlıklı olmadığg düşünülen 17 veri analiz dışı tutulmuştur. Veriler SPSS 21 programı ile bilgisayar ortamında analiz edilmiştir. Dağılımın normalliğini belirlemek amacıyla, örneklemdeki kişi sayısı 50'nin üzerinde olduğu için Kolmogorov-Smirnov Normallik Testi $(Z=1.26 ; \mathrm{p}=.082)$ yapılmıştır. Ulaşılan bu değer .05 'ten büyük olduğu için normallik varsayımımın sağlandığı söylenebilir (Büyüköztürk, 2003). Bu işlemin ardından verilerin çoklu bağlantı özelliklerini tespit etmek 
için tolerans ve varyans genişlik faktörü (VIF) değerleri hesaplanmıştır. VIF değeri 10 ve daha yüksek olduğunda kuvvetli bağımlılık olduğu kabul edilmektedir (Smith ve Campell, 1980). Bu araştırmanın değişkenlerine ait VIF değerleri 1.19 ile 1.81 arasında, tolerans değerleri ise 0.42 ile 0.68 arasında değişmiştir. $\mathrm{Bu}$ bulgular değişkenler arasında çoklu bağlantı problemi olmadığını göstermiştir. Değişkenler arasındaki ilişkilere Pearson Momentler Çarpımı Korelasyon Analizi, genel psikolojik sağlık ve psikolojik kırılganlık puanlarının beraber öznel zindeliği yordamasına ise Hiyerarşik Regresyon Analizi ve Sobel Testi ile bakılmıştır.

\section{Bulgular ve Yorumlar}

$\mathrm{Bu}$ kısımda, araştırma verilerinin analizi sonucunda elde dilen istatistiksel analizlere dair bulgular tablolaştırılarak verilmiştir.

\section{1. Öznel Zindelik Puanları ile Psikolojik Kırılganlık ve Genel Psikolojik Sağlık Arasındaki İlişkiler}

Tablo 1. Genel Psikolojik Sağlık, Psikolojik Kırılganlık ve Öznel Zindelik Puanları Arasındaki İlişkileri Belirlemek İçin Yapılan Pearson Momentler Çarpımı Korelasyon Hesabı Sonuçları

\begin{tabular}{lccc}
\hline Değişkenler & $\mathbf{1}$ & $\mathbf{2}$ & $\mathbf{3}$ \\
\hline 1. Genel Psikolojik Sağlık & 1 & & \\
2. Psikolojik Kırılganlık & $.47 * * *$ & 1 & \\
3. Öznel Zindelik & $-.62^{* * *}$ & $-.33^{* * *}$ & 1 \\
Ortalama $(\overline{\mathrm{X}})$ & 13.85 & 16.11 & 31.72 \\
Standart Sapma (SS) & 6.39 & 5.04 & 8.97 \\
\hline
\end{tabular}

Tablo 1 incelendiğinde; üniversite öğrencilerinin genel psikolojik sağlıkları ile öznel zindelik puanları arasında ters yönde anlamlı bir ilişki $(\mathrm{r}=-.62 ; \quad \mathrm{p}<.00)$ olduğu belirlenmiştir. Ayrıca öğrencilerin psikolojik kırılganlık puanları ile öznel zindelik puanları arasında da $(\mathrm{r}=-.33$; $\mathrm{p}<.05)$ ters yönde anlamlı bir ilişki olduğu belirlenmiştir. Son olarak öğrencilerin psikolojik kırılganlıkları ile genel psikolojik sağlık puanları arasında ise $(r=.47 ; \mathrm{p}<.05)$ pozitif yönde anlamlı bir ilişki olduğu belirlenmiştir.

2. Psikolojik Kırılganlık ile Öznel Zindelik Arasındaki İlişkide Genel Psikolojik Sağlığın Aracı Rolü

Genel psikolojik sağlığın psikolojik kırılganlık ile öznel zindelik arasındaki ilişkide aracı değişken olup olmadığını test etmek üzere Hiyerarşik Regresyon Analizi yapılmıştır. Araştırmada, psikolojik kırılganlık öznel zindeliği yordayıcı değişken, genel psikolojik sağlık ise aracı değişken olarak alınmıştır. Hiyerarşik regresyon analizi yoluyla aracı değişkenlerin rolü incelenirken Baron ve Kenny (1986)'nin önerdiği kıstaslar izlenmiştir. Bu kıstaslardan ilki; yordanan değişkenin (öznel zindelik), yordayıcı değişken (psikolojik kırılganlık) ve aracı değişken (genel psikolojik sağlık) ile ayrı ayrı anlamlı bir ilişkisinin olması gerekmektedir. Bir diğer kıstasa göre, aracı değişken ile yordayıcı değişken arasında anlamlı bir ilişki olmalıdır. Son kıstasa göre ise, aracı değişken ve yordayıcı değişken eş zamanlı olarak analize girildiğinde yordayıcı ve yordanan değişken arasındaki var olan ilişki ya tamamen ortadan kalkmalı ya da azalmalıdır. Araştırmadaki değişkenler arasındaki ilişkileri saptamak amacıyla yapılan regresyon analizlerine dayalı yol (path) grafiği Şekil 1'de verilmiştir.

Yukarıda belirtilen kriterler doğrultusunda yapılan Hiyerarşik Regresyon Analizi Tablo 2'de verilmiştir. Regresyon analizine ilk aşamada psikolojik kırılganlık değişkeni ikinci adımda ise genel psikolojik sağlık değişkeni konulmuştur. Regresyon analizi sonuçları, ilk aşamada denkleme girilen psikolojik kırılganlık değişkeninin öznel zindelik puanlarındaki varyansın \%11'inin açıkladığını göstermektedir $(\beta=-.33, \mathrm{t}=-6.57$, $\mathrm{p}<.001)$. İkinci aşamada genel psikolojik sağlık değişkeninin denkleme girilmesiyle açıklanan varyans yaklaşık \%39'a yükselmiştir ( $\beta=-.59, \mathrm{t}=-12.59, \mathrm{p}<.001)$. Bu sonuçlara göre; psikolojik kırılganlığın modele anlamlı katk1 sağladığ1 yani; öznel zindeliğin anlamlı yordayıcısı olduğu bulunmuştur. Öte yandan Tablo 2'de görüldüğü gibi, aracı değişken olarak denkleme dahil edilen genel psikolojik sağlı analize dahil edildikten sonra psikolojik kırılganlığın öznel zindelik üzerindeki anlamlı etkisinin ortadan kalktığı, $\beta$ değerinin -.33'den -.05'e düştüğü tespit edilmiştir.

Tablo 2.Üniversite Öğrencilerinin Öznel Zindelik Puanlarının Yordanması

\begin{tabular}{|c|c|c|c|c|c|c|}
\hline \multirow{2}{*}{\multicolumn{2}{|c|}{ Yordayıcı Değişken }} & \multicolumn{5}{|c|}{$\ddot{O ̈ z n e l ~ Z i n d e l i k ~}$} \\
\hline & & $R^{2}$ & $R^{2}$ de ğişim & $\beta$ & $t$ & $F$ \\
\hline Aşama 1 & Psikolojik Kırılganlık & .11 & .11 & -.33 & -6.57 & $43.28 * *$ \\
\hline \multirow{2}{*}{ Aşama 2} & Psikolojik Kırılganlık & \multirow{2}{*}{.39} & \multirow{2}{*}{.39} & -.05 & -1.08 & \multirow{2}{*}{$110.64 * * *$} \\
\hline & Genel Psikolojik Sağlik & & & -.60 & -12.59 & \\
\hline
\end{tabular}

$* * * p<.001$

Baron ve Kenny (1986)'e göre, yordayıcı değişkenin etkisinin tümüyle ortadan kalkması sözkonusu ilişkide genel psikolojik sağlığın "tam aracı değişken" olduğuna işaret etmektedir. Bahsedilen aracılık rolünün genel psikolojik sağlıktan kaynaklandığı görülmektedir. Aracılık 
rolünün sınanması için Baron ve Kenny (1986)'nın daha önce bahsedilen şartları sağlanmış olmakla birlikte; aracı değişken olma özelliğinin istatistiksel anlamlılığı görebilmek amacıyla Sobel Testi yapılmıştır. Sobel Testi sonuçları; genel psikolojik sağlığın $(\mathrm{z}=6.19, \mathrm{p}<.001)$ psikolojik kırılganlık ile öznel zindelik arasındaki ilişkide "tam aracılık rolü"nü istatistiksel olarak doğrulamaktadır (Şekil 1). Bu bulguya göre; üniversite öğrencilerinin psikolojik kırılganlıklarının artması olumsuz genel psikolojik sağlığı arttırmakta, bu durum da öznel zindeliği düşürmektedir.

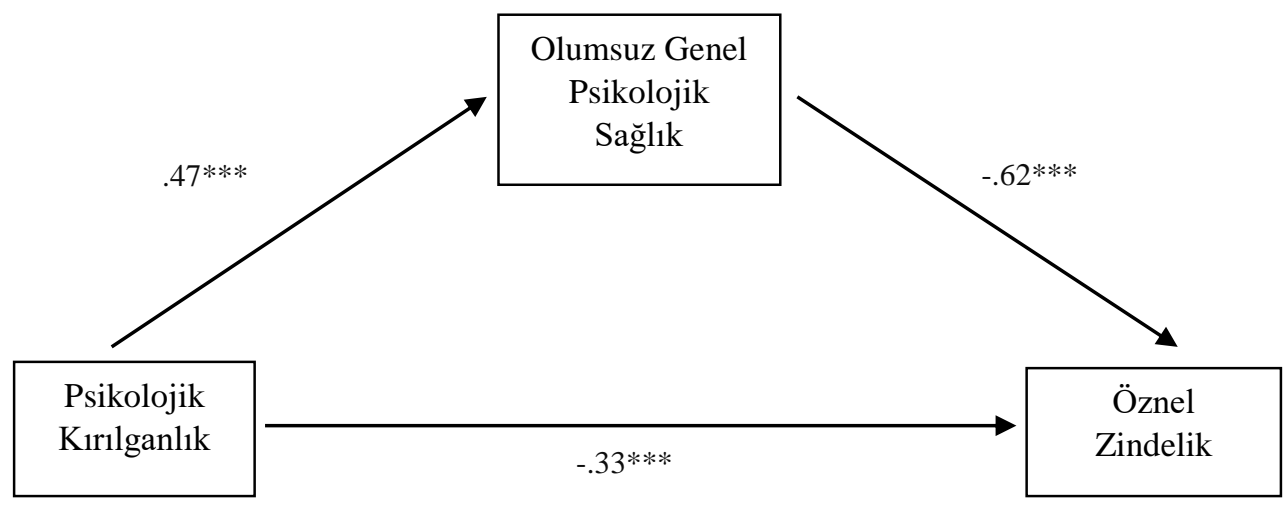

Şekil 1. Psikolojik Kırılganlık ile Öznel Zindelik Arasındaki İlişkide Olumsuz Genel psikolojik Sağlığın Aracı Rolüne İlişkin Yol Haritaları

\section{Tartışma, Sonuç ve Öneriler}

$\mathrm{Bu}$ araştırmada, üniversite öğrencilerinde psikolojik kırılganlık ile öznel zindelik arasındaki ilişkide genel psikolojik sağlığın aracı rolünün olup olmadığ incelenmiştir. Araştırmada öncelikle değişkenler arasındaki ilişkiler ayrı ayrı ele alınmıştır. Yapılan analizler sonucunda ilk adımda katılımciların genel olumsuz psikolojik sağlıkları ve öznel zindelikleri arasında ters yönde anlamlı bir ilişki saptanmıştır. Bireyin zinde, coşkulu ve diri olması anlamına gelen öznel zindeliğin; kişinin psikolojik, fizyolojik ve bilişsel olarak sağlıklı olmasını ifade eden genel psikolojik sağlık ile olumlu bir ilişki içerisinde olması yapılmış farklı çalışmalarla uyumluluk göstermektedir (Akın ve Akın, 2015). Bireylerin yaşamdan aldıkları haz, yüksek benlik değerine sahip olma, dışa dönüklük, aktiflik ve pozitif duygulara sahip olmalarının genel psikolojik sağlıklarının yerinde olmasıyla doğrudan ilişkili olduğu ifade edilmektedir. Bu kavramların öznel zindelik ile olan ilişkilerine dair yapılan araştırmalar aralarında olumlu bir ilişki olduğunu göstermektedir (Ryan ve Fredick, 1977).

Araştırmanın diğer bulgusuna göre, bireylerin psikolojik kırılganlık puanları ile öznel zindelik puanları arasında ters yönde anlamlı bir ilişki saptanmıştır. Psikolojik kırılganlık düzeyi yüksek olan bireylerin benlik değerleri dışa bağlı olarak geliştiği için bu bireylerin dişsal onay arayışları yüksektir. Alan yazın incelendiğinde psikolojik kırılganlık düzeyi yüksek olan bireylerin diğer insanlara göre daha fazla olumsuz duygu durumu içerisinde oldukları, hem ruhsal olarak hem bedensel olarak bu durumdan olumsuz etkilendikleri görülmektedir (Sinclair ve Wallston, 1999). Ayrıca psikolojik kırılganlık bir kişilik özelliği olarak da ele alınabilir. Bu bağlamda Savcı ve Aysan'ın (2016) yaptıkları araştırmalarında kişilik özelliklerinin bireylerin öznel zindelik ve psikolojik iyi oluşlarının anlamlı bir yordayıcısı olduğunu ortaya koymaktadır. Benzer bir bulgu olarak; Çelik ve Topçuoğlu (2017) da üniversite öğrencileri üzerinde yaptıkları araştırmalarında, olumlu bir kişilik özelliği olan ve psikolojik kırılganlı̆̆ı içermeyen proaktif kişilik özellikleri ile öznel zindelik arasında pozitif anlamlı bir ilişki olduğu bulgusuna ulaşmışlardır. $\mathrm{Bu}$ araştırmalar ruhsal ve bedensel olarak iyilik halinde olmayan bireylerin öznel zindeliklerinin de düşük olmasını destekler niteliktedir. Öte yandan, psikolojik kırılganlık düzeyleri yüksek olan bireylerin sosyal ortamlarda kendilerini yetersiz algıladıkları görülmüş̧ür (Ingram ve Price, 2010; Levine, 2004). Sarıçalı ve Satıcı da (2017) yaptıkları araştırmada, bireylerin psikolojik kırılganlıkları ile utangaçlık düzeyleri arasında pozitif anlamlı bir ilişki olduğu bulgusuna ulaşmışlardır. $\mathrm{Bu}$ durum bireylerin toplumda aktif bir şekilde var olmalarını kısıtlayıcı niteliktedir. $\mathrm{Bu}$ araştırmalar psikolojik kırılganlık düzeyleri yüksek olan bireylerin; öznel zindelik düzeylerinin düşük olması bulgusunu desteklemektedir.

Araştırma bulguları incelendiğinde, bireylerin olumsuz genel psikolojik sağlıkları ile psikolojik kırılganlıkları arasında pozitif yönde anlamlı bir ilişki olduğu belirlenmiştir. Elde edilen bu bulgu alan yazındaki bilgilerle ve yapılan bazı araştırmalarla tutarlık içindedir. Daha önce de değinildiği gibi, bireylerin psikolojik kırılganlıkları arttıkça yaşama dair umut düzeyleri azalmakta, kırılganlığa bağlı olarak duyulan kayg1 düzeyleriyle genel psikolojik sağlıklarını olumsuz etkilemektedir (Cheeck ve Buss, 1981; Satıc1, 2016; Satıc1, Kayıs ve Akın, 2013).

Son olarak, araştırmanın asıl amacını yansıtan psikolojik kırılganlık ve öznel zindelik arasında genel olumsuz psikolojik sağlığın aracı rolünü araştıran analizler sonucunda; genel olumsuz psikolojik sağlığın tam aracı rol üstlendiği sonucuna ulaşılmıştır. Kurulan modelde psikolojik kırılganlığın, öznel zindelik üzerinde var olan etkisinin genel olumsuz psikolojik sağlığın devreye girmesiyle ortadan kalktığı görülmüştür. Elde edilen bu bulgu bireylerin öznel zindelikleri üzerinde genel psikolojik sağlığın etkisinin psikolojik kırılganlık değişkeninden daha 
fazla etkili olduğunu göstermektedir. Öznel zindelik, öznel iyi oluşu içinde barınan bir kavramdır. Öznel iyi oluşun bilişsel ve duygusal olmak üzere iki boyutundan söz edilebilir. Bu boyutlardan biri entelektüel ve ya gerçekçi yönü içeren bilişsel boyut; diğeri ise olumlu ve olumsuz duygulanımı içeren duygusal boyuttur (Andrews ve Robinson, 1991). Bireyin sevinçli, istekli, canlı, uyanık olması olumlu; öfkeli, korkmuş hissetmesi ise olumsuz yönüdür (Ben-Zur, 2003). Birey korku, öfke, nefret gibi olumsuz duyguları hissediyorsa öznel iyi oluşun duygusal boyutunun olumsuz yönüne daha yakındır. Gökçe (2013) yaptığı araştırmada bireylerin genel psikolojik sağlıkları ile duygu düzenleme güçlükleri ve dürtü kontrolleri arasında anlamlı ilişkiler olduğunu bulmuştur. Duygu düzenleme güçlükleri ve dürtü kontrolünün öznel zindelik ile negatif ilişsili kavramlar olduğu düşünüldüğünde, bu araştırmanın bulgularının da bu çalışmanın sonuçlarını destekleyici nitelikte olduğu söylenebilir. Benzer bir çalışma olarak, Salama-Younes'in (2011) üniversite öğrencileri örneklemiyle yaptığı araştırmasında da pozitif ruhsal sağlık ile öznel zindelik arasında pozitif yönde yüksek bir ilişki olduğu görülmüştür. $\mathrm{Bu}$ araştırmalar genel psikolojik sağlığı yerinde olmayan bireylerin öznel zindelik düzeylerinin düşük olacağını göstermektedir. Psikolojik sağlığı yerinde olmayan bireyin davranışlarının buna göre şekillendiği göz önüne alındığında; öznel zindeliğin getirdiği uyanıklık, aktiflik ve özellikle de girişkenlik duygularını olumsuz olarak etkileyeceği söylenebilir. Bu da bireyin sağlıklı bir ruh haline sahip olmasını olumsuz yönde etkileyerek öznel zindelik düzeyinin düşmesine neden olacaktır. Özetle, bireylerin öznel zindelikleri üzerinde genel psikolojik sağlıklarının etkisi psikolojik kırılganlık gibi bazı başka değişkenlere göre çok daha yüksektir. Bu bilgiler çerçevesinde elde edilen bulgunun kuramsal perspektiften de desteklendiği ileri sürülebilir.

Araştırma bulgularına göre, üniversite öğrencilerinin genel psikolojik sağlıkları ile hem öznel zindelikleri hem de psikolojik kırılganlıkları arasında anlamlı ilişkiler olduğu görülmüştür. $\mathrm{Bu}$ bulgudan hareketle, üniversitelerin öğrencilerine yönelik psikolojik danışma birimleri kurmalarının öğrencilerin ruh sağlığı açısından oldukça önemli olacağı düşünülmektedir. Alan çalışanları ile ilgili olarak; öznel zindelikle ilişkili olduğu görülen psikolojik kırılganlık ve genel psikolojik sağlık konularının öncelikle ailelerde şekillendiği bilinmektedir. Bu bağlamda aileleri bilgilendirici ve davranış şekillendirmeye yönelik eğitimlerin düzenlenmesinin yararlı olacağı düşünülmektedir. $\mathrm{Bu}$ araştırma sadece bir eğitim fakültesi örneklemi ile sınırlı kalmıştır. Dolaysıyla araştırmanın daha kapsamlı ve değişik fakülteleri de kapsayan farklı örneklem yapılarını içeren bir şekilde yeniden ele alınmasının yararlı olacağı düşünülmektedir. $\mathrm{Bu}$ noktada, özellikle farklı araştırma yöntemleri ve desenleri ile uygulamaya dönük bilimsel çalışmaların yapılması yararlı olacaktır. Ayrıca pozitif psikoloji alanında yapılan çalışma sayısı son yıllarda oldukça artmış olmakla beraber, bu araştırmadaki değişkenleri başka değişkenlerle (cinsiyet, sosyo-ekonomik düzey, medeni durum vb.) ele alan yeni çalışmaların yapılmasının ilgili alanı zenginleştireceği düşünülmektedir. Öte yandan tüm eğitim kademelerinde öğrencilere yönelik, önleyici rehberlik hizmetleri kapsamında psikoeğitim çalışmalarının yapılmasının da önemli olduğu söylenebilir.

\section{Kaynakça}

Akın, A. ve Eker, H. (2011). Turkish version of the Psychological Vulnerability Scale: A study of validity and reliability. Paper presented at the 32th International Conference of the Stress and Anxiety Research Society (STAR), July, 18-20, Münster, Germany.

Akın, A. ve Akın, U. (2015). Arkadaşlık kalitesi ve öznel mutluluk: Öznel zindeliğin aracılık rolü. Eğitim ve Bilim, 40(177), 233-241.

Andrews, F. M. and Robinson, J. P. (1991). Measures of subjective well-being. (Ed. Robinson, J. P., Shaver, P. R. ve Wrightsman, L, S.) Measures of personality and social psychological attitudes. Vol. I, New York: Academic Press.

Baron, R. M. and Kenny, D. A. (1986). The moderatormediator variable distinction in social psychological research: Conceptual, strategic and statistical considerations. Journal of Personality and Social Psychology, 51, 1173-1182.

Ben-Zur, H. (2003). Happy adolescents: The link between subjective well-being, internal resources and parental factors. Journal of Youth and Adolescence, 32(2), 6779.

Bostic, T. J., Rubio, D. M. and Hood, M. (2000). A validation of the subjective vitality scale using structural equation modeling. Social Indicators Research, 52(3), 313-324.

Brunstein, J. C. and Maier, G. W. (2002). Das Strebennach persön lichen Zielen: Emotionales Wohlbefindenund proaktive Entwicklungüber die Lebensspanne. Persön lich keitunden twicklung. Weinheim: Beltz: 157-190.

Büyüköztürk, Ş. (2003). Sosyal bilimler için veri analizi el kitab1. Ankara: Pegem Yayınları.

Can, B. (2017). Fiziksel kırılganlık. Türkiye Klinikleri, Journal of Geriatrics-Special Topics, 3(1), 1-5.

Cansever, G. (1976). İçimdeki ben. İstanbul: Boğaziçi Üniversitesi Yayınları.

Cheek, J. M. and Buss, A. H. (1981). Shyness and sociability. Journal of Personality and Social Psychology, 41(2), 330-339.

Clark, D. O., Stump, T. E., Miller, D. K. and Long, J. S. (2007). Educational disparities in the prevalence and consequence of physical vulnerability. Journal of Gerontology: Social Science, 62(3), 193-197.

Corey, G. (2008). Psikolojik danışma ve psikoterapi kuram ve uygulamaları.(T. Ergene, Çev.) Ankara: Mentis Yayıncilik.

Crocker, J. (2002). Contingencies of self-worth: Implications for self-regulation and psychological vulnerability. Self and Identity, 1(2), 143-149.

Crocker, J. and Park, L. E. (2003). Seeking self-esteem: Construction, maintenance, and protection of self worth. In M. Leary ve J. Tangney (Eds.), Handbook of Self and Identity, (pp. 291-313). New York:Guilford Press. 
Çelik, E. ve Topçuoğlu, P. (2017). Proaktif kişiliğin öznel zindelik ile merak arasındaki ilişkide aracılık etkisi. Abant İzzet Baysal Üniversitesi Eğitim Fakültesi Dergisi, 17(3), 1221-1240.

Diener, E., Suh, E. M., Lucas, R. E. and Smith, H. L. (1999). Subjective well-being: Three decades of progress. Psychological Bulletine, 125(2), 276-302.

Ekşi, H., Bikeç, S. M. ve Ümmet, D. (2017). Öğretmen adaylarında kendini sansürleme, psikolojik kirllganlı ve koşullu öz değer. Küreselleşen dünyada eğitim el kitabı (ss. 440-450) Ankara: Pegem Yayıncılık.

Fraser, M. W., Richman, J. M. ve Galinsky, M. J. (1999). Risk, protection, and resilience: Toward a conceptual framework for social practice. Social Work Research, 23, 129-208.

Gable, S. L. and Haidt, J. (2005). What (andwhy) is positive psychology? Review of General Psychology, 9(2), 103-110.

Greene, R. (2002). Resilience: An integrated approach to practice, policy, and research. Washington, DC: NationalAssociation of SocialWorkersPress.

Gökçe, G. (2013). Ebeveynin duygusal erişilebilirliği ve genel psikolojik sağlık: Duygu düzenleme, kişilerarası ilişki tarzı ve sosyal desteğin rolü. Yüksek lisans tezi. Ankara Üniversitesi.

Ingram, R. E. and Price, J. M. (2010). Understanding psychopathology: The role of vulnerability. In R. E. Ingram and J. M. Price (Eds.) Vulnerability to Psychopathology: Risk across the Lifespan(pp. 3-17). New York: Guilford Press.

Karasar, N. (1999). Bilimsel araştırma yöntemi. Ankara: Nobel Yayıncılık.

Keyes, C, L. and Lopez, S. J. (2002). Toward a science of mental health: Positive directions in diagnosis and interventions. In C. R. Snyder ve S. J. Lopez (Eds.), Handbook of positive psychology (pp.45-59). London: Oxford University Press.

Kılıç, C. (1996). Genel sağlık anketi: Güvenirlilik ve geçerlilik çalışması. Türk Psikiyatri Dergisi, 7,3-9.

Kuzgun, Y. (1972). Kendini gerçekleştirme. Ankara Üniversitesi Dil ve Tarih-Coğrafya Fakültesi Felsefe Bölümü Dergisi, 10(1), 162-178.

Levine, C. (2004). The concept of vulnerability in disaster research. Journal of Traumatic Stress, 17(5), 395-402.

Mongrain, M. and Blackburn, S. (2005). Cognitive vulnerability, life time risk, and there currence of majör depression in graduate students. Cognitive Therapy and Research, 29(6), 747-768.

Murphy, L. B. (1987). Further reflections on resilience. (Ed: E. J. Anthony ve B. J. Cohler) The Invulnerable Child. New York: The Guilford Press.

Özdamar, K. (2003). SPSS ile biyoistatistik. Eskişehir: Kaan kitabevi.
Pawelski, J. O. (2003). William James, positive psychology, and healthy mindness. Journal of Speculative Philosophy, 17(1), 53-67.

Ryan, R. M. ve Frederick, C. (1997). On energy, personality, and health: Subjective vitality as a dynamic reflection of well-being. Journal of Personality, 65(3), 529-565.

Salama-Younes, M. (2011). Positive mental health, subjective vitality and satisfaction with life for french physical education students. World Journal of Sport Sciences 4(2), 90-97.

Sarıçlı, M. ve Satıcı, A. S. (2017). Bilinçli farkındalık ile psikolojik kırılganlık ilişkisinde utangaçlığın aracı rolü, Hitit Universitesi Sosyal Bilimler Enstitüsü Dergisi, 10(1), 655-670.

Sarıçam, H., İlbay, A. B., Uysal, R., Çardak, M. ve Akın, A. (2012). Turkish version of the short form of resilience appraisal scale: The validity and reliability study. In International Counseling and Education Conference, İstanbul Technical University, Istanbul, Turkey. (pp. 3-5).

Satıc1, S. (2016). Psychological vulnerability, resilience, and subjective well-being: The mediating role of hope. Personality and Individual Differences, 102, 68-73.

Satıcı, S. A., Kayıs, A. R. ve Akın, A. (2013). Predictive role of authenticity on psychological vulnerability in Turkish university students. Psychological reports: mentaland physicalhealth, 112(2), 519-528.

Savcı, M. ve Aysan, F. (2016). Kişilik özelliklerinin öznel zindelik ve psikolojik iyi oluşa etkisi VII. Uluslararası Ĕ̈itim Araştırmaları Kongresi Bildiri Kitabı, 5-8 Mayıs 2016 Çanakkale.

Scanlon, A. and Lee, G. A. (2007). Theuse of the term vulnerability in acutecare: Why does it differ Sand what does it mean? Australian Journal of Advanced Nursing, 24(3), 54.

Seligman, M. E. (2002). Positive psychology, positive prevention, and positive therapy. Handbook of Positive Psychology, (2) 3-12.

Sinclair, V. G. and Wallston, K. A. (1999). The development and validation of the Psychological Vulnerability Scale. Cognitive Therapy and Research, 23(2), 119-129.

Smith, G. and Campbell, F. (1980). A critique of some ridge regression methods. Journal of the American Statistical Association, 75(3), 74-103.

Uysal, R., Sarıçam, H. ve Akın, A. (2014). Öznel zindelik ölçeği Türkçe formunun psikometrik özellikleri. Sosyal ve Beşeri Bilimler Araştırmaları Dergisi, 33, 136-146.

Windle, M. (1999). Critical conceptual and measurement issues in the study of resilience. In. M. D. Glantz veJ. L. Johnson (Eds.) New York: Kluwer Academic/Pelnum Publishers. 